\author{
Mato Perić \\ Bestprojekt Ltd \\ Petrovaradinska 7 \\ 10000 Zagreb \\ Croatia \\ Zdenko Tonković \\ Faculty of Mechanical Engineering and \\ Naval Architecture \\ Ivana Lučića 5 \\ 10000 Zagreb \\ Croatia \\ Katarina S. Maksimović \\ Research Associate \\ City Administration of the City of Belgrade \\ 11000 Belgrade \\ Dragi Stamenković \\ Research Assistant \\ Visoka brodarska škola \\ akademskih studija \\ Bulevar vojvode Mišića 37 \\ 11000 Belgrade
}

\section{Numerical Analysis of Residual Stresses in a T-Joint Fillet Weld Using a Submodeling Technique}

\begin{abstract}
A submodeling technique is applied in the framework of this study on a Tjoint fillet weld example in order to check finite element mesh sensitivity as well as to obtain more accurate temperatures, displacements and residual stress fields in the weld and its vicinity where the temperature and stress gradients are very high. The submodeling procedure of the welding process is demonstrated step-by-step. The obtained results of the temperature, residual stress and displacement distributions correspond very well with the experimental measurements and analytical solutions from the literature.
\end{abstract}

Keywords Submodeling, T-joint fillet weld, finite element analysis, residual stress, welding distortion, Abaqus, welding simulation

\section{INTRODUCTION}

Welding is one of the most frequently used engineering methods of joining structural components in many industrial fields. Large localised heat input during welding and subsequent rapid cooling of melted materials can have as a harmful consequence permanent residual stresses and geometrical imperfection occurrences in the welded structures. Such geometrical imperfections can cause serious problems during structure assembly, while high tensile residual stresses in combination with the workload can have a detrimental impact on its integrity and life-time [1-4].

The elimination of these consequences by using post-weld thermal or mechanical treatments requires extended production time and causes additional financial expenses. For these reasons, it is highly desirable to know the magnitude of residual stresses and distortions in the structure as early as the design phase. Due to the rapid progress of computer technology in recent decades, the numerical calculations of residual stresses and distortions have become an unavoidable tool for predicting these phenomena by shifting expensive experiments to computationally based procedures [5-9]. The main problem that exists here is the long-time duration of numerical simulations in models with a large number of finite elements.

To overcome this problem, there are many suggested solutions in the literature. Shen and Chen [10], Rong et al. [11], Perić et al. [12,13] and Rezaei et al. [14] proposed various solutions based on coupling shell and three-dimensional finite elements that significantly reduce the calculation time. Huang and Murakawa [15] developed in their study a dynamic mesh refining method

Received: September 2018, Accepted: November 2018

Correspondence to: Mato Perić

Bestprojekt Ltd., Petrovaradinska 7

10000, Zagreb, Croatia

E-mail: mato.peric@fsb.hr

doi:10.5937/fmet1901183P

(c) Faculty of Mechanical Engineering, Belgrade. All rights reserved to speed up the calculation process that significantly reduces the number of freedom in a finite element model. Most of the suggested solutions above are related to the reduction of calculation time primarily in the processing phase. For time-reduction in the pre-processing phase, there are only limited data in the literature provided. In that sense, Seleš et al. [16] and Elmesalamy et al. [17] used Abaqus Plug-in Software (AWI) to speed-up the modeling of thermal loads and boundary conditions that greatly reduce the model preparation time. Furthermore, it is well known that the size of finite element meshes has a great influence on the result accuracy and computational time, so that the finite element calculations with refined meshes have to be done several times in a row $[18,19]$ before tackling the numerical simulation of the welding process. This approach is often unsuitable for engineering applications, especially for models with a large number of finite elements, since it consumes too much computational time. For this reason, the submodeling technique in this study which is based on globallocal transition is applied to check the finite element mesh sensitivity as well as to obtain finer residual stress and displacement distribution in the area of interest.

In the submodeling technique, the results from the global model are interpolated onto the nodes on the appropriate parts of the submodel boundary. As the submodel region has a finer mesh, the submodel can provide an accurate, detailed solution. Unlike a large number of papers where the submodeling capability is used in the mechanical analysis to obtain a distribution of high stresses caused by geometric discontinuities [20], a very limited number of studies have been reported in the area dealing with submodeling techniques in the thermomechanical analysis of welding processes [21, 22].

This paper is organized as follows: Section 2 provides a brief description of the submodeling application on a welding simulation process. The numerical model is presented in Section 3. Section 4 gives a comparison of temperatures, deflections and residual stresses obtained using the submodeling technique with the results from 
literature as well as with the results from the global model. Finally, some concluding remarks are given in the last section.

\section{WELDING SIMULATION USING SUBMODELING TECHNIQUE}

The principle of the submodeling technique for the simulation of the welding process consists of four steps and it is given in Fig. 1. In the first step, a heat transfer analysis is done to obtain temperature-time history at each node on the global model. The obtained thermal field is then used as a thermal load in the mechanical analysis in the second step to obtain residual stresses and displacements. The obtained temperature histories on the global model boundary nodes are then transferred as driven variables from the global model boundaries onto the submodel ones in the third step. Finally, in the fourth step, the obtained submodel temperature histories from the third step are then applied as a thermal load in the fourth step, while the displacement obtained from the global model boundaries from the second step are simultaneously used as driven variables. Since the submodel dimensions are usually significantly less than the global ones, this allows for much denser finite element meshes (mesh-2) in the submodel analysis.

\section{NUMERICAL MODEL}

To verify the submodel technique, a T-joint fillet weld with experimentally measured plate deflections is taken from the literature [23]. The dimensions of the welded model with mechanical restraints are given in Fig. 2. A two single pass MAG welding with no time-gap between the weld passes is used. The welding parameters are as follows: welding voltage $U=29 \mathrm{~V}$, welding current $I=270 \mathrm{~A}$, welding speed $v=400$ $\mathrm{mm} / \mathrm{min}$ and angle of torch $\alpha=45^{\circ}$. The plates are made of SM400A carbon steel which chemical compositions are given in Table 1, while its thermal and mechanical properties are given in Figs. 3 and 4.

Table 1. Chemical composition of SM400A steel [23]

\begin{tabular}{|l|l|l|l|l|l|}
\hline Elements & $\mathrm{C}$ & $\mathrm{Si}$ & $\mathrm{Mn}$ & $\mathrm{P}$ & $\mathrm{S}$ \\
\hline Mass $\%$ & 0.23 & - & 0.56 & $<0.0035$ & $<0.0035$ \\
\hline
\end{tabular}

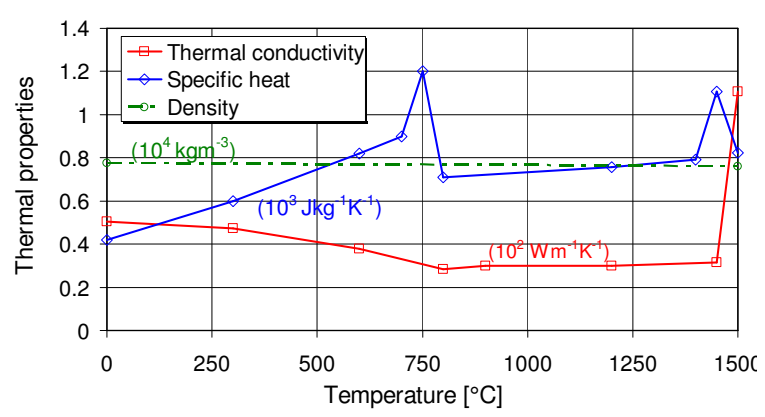

Figure 3. Thermal properties of SM400A steel [24]

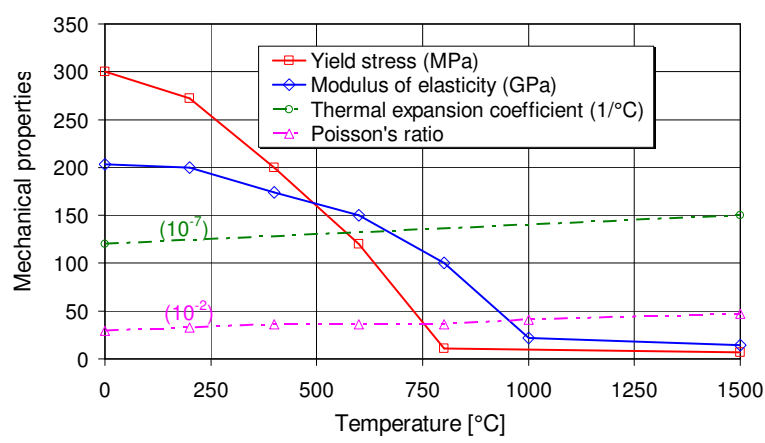

Figure 4. Mechanical properties of SM400A steel [24]

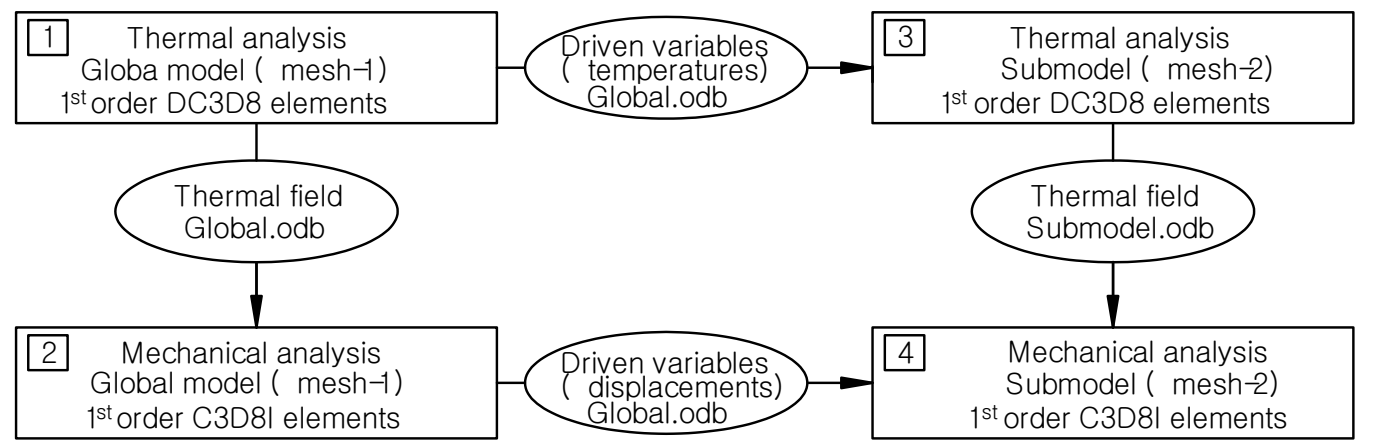

Figure 1. Sheme of welding submodeling technique

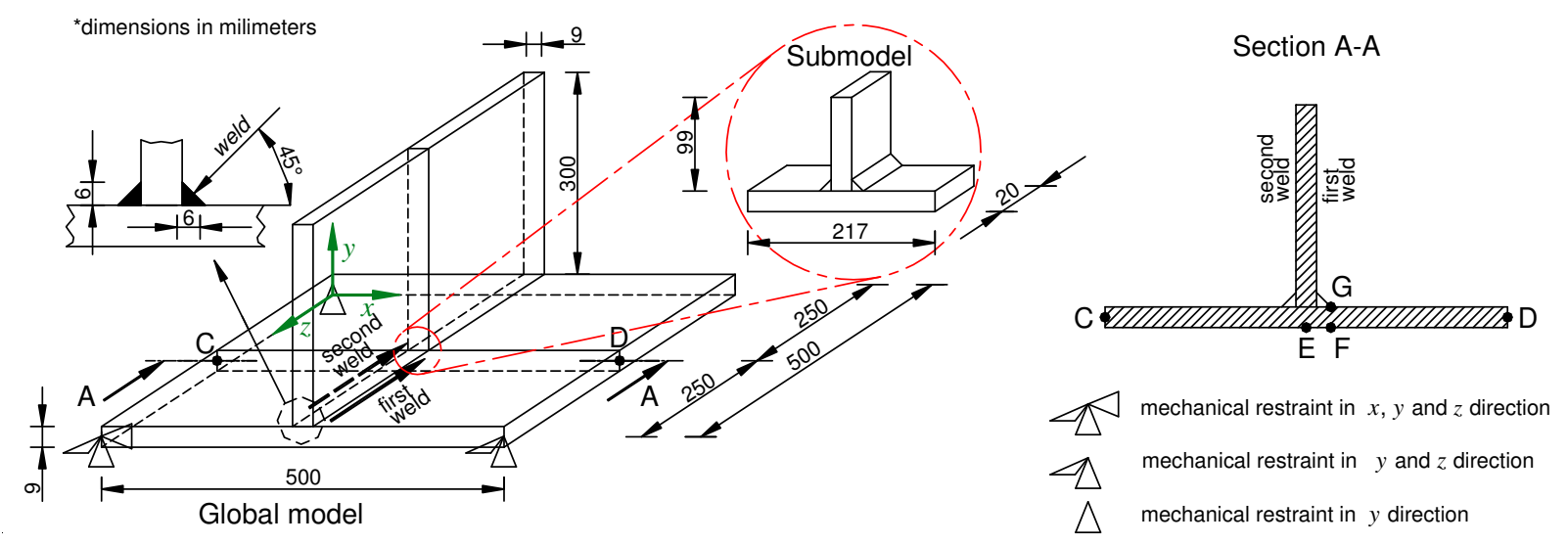

Figure 2. Geometry of T-joint welded plates 
As it can be seen in Fig. 1, a sequentially coupled numerical simulation of welding process is applied in this study. It means that a full analysis consists of two independent analyses: thermal and mechanical ones. In the thermal analysis, the governing equation for transient nonlinear heat transfer is given in the form of

$$
\frac{\partial}{\partial x}\left(k_{x} \frac{\partial T}{\partial x}\right)+\frac{\partial}{\partial y}\left(k_{y} \frac{\partial T}{\partial y}\right)+\frac{\partial}{\partial z}\left(k_{y} \frac{\partial T}{\partial z}\right)+Q=\rho C \frac{\partial T}{\partial t}
$$

where $k_{x}, k_{y}$, and $k_{z}$ are the thermal conductivities in the $x, y$ and $z$ directions, respectively; $T$ is the temperature; $Q$ is the heat input; $\rho$ is the material density; $C$ is the specific heat capacity; and $t$ is the time, respectively. A general solution of Eq. (1) can be obtained by introducing the following initial and boundary conditions

$$
\begin{aligned}
& T(x, y, z, 0)=T_{0}(x, y, z) \\
& \left(k_{x} \frac{\partial T}{\partial x} N_{x}+k_{y} \frac{\partial T}{\partial y} N_{y}+k_{z} \frac{\partial T}{\partial z} N_{z}\right)+q_{s}+ \\
& +h_{c}\left(T-T_{\infty}\right)+h_{r}\left(T-T_{r}\right)=0
\end{aligned}
$$

where $N_{x}, N_{y}$, and $N_{z}$ are the direction cosine of the normal to the boundary; $h_{c}$ and $h_{r}$ are the convection and radiation heat transfer coefficients, respectively; $q_{s}$ denotes the boundary heat flux; $T_{r}$ denotes the temperature of radiation; and $T_{\infty}$ represents the ambient temperature. Radiation heat loses can be expressed by the following equation

$$
h_{r}=\sigma \varepsilon F\left(T^{2}+T_{r}^{2}\right)\left(T+T_{r}\right)
$$

where $\sigma=5.67 \times 10^{-8} \mathrm{Jm}^{-2} \mathrm{~K}^{-4}$ denotes the StefanBoltzmann constant, $\varepsilon$ is the surface emissivity factor, and $F$ is the configuration factor. The total heat input applied to the weld is given by:

$$
Q=\frac{\eta U I}{V_{H}}
$$

where $\eta$ represents the heat input efficiency, $I$ is welding current, $U$ is the arc voltage, and $V_{H}$ is the volume of the activated set of finite elements. In the thermal analysis of this study, the filler metal addition is simulated by element birth and death technique. The segmented heat flux with uniformly distributed $Q=5.22 \times 10^{10} \mathrm{Jm}^{-3} \mathrm{~s}^{-1}$ per weld volume is applied and it is calculated according to Eq. (5). Additionally, the following thermal boundary conditions are assumed: convective heat transfer coefficient $k=10 \mathrm{Wm}^{-2} \mathrm{~K}^{-1}$, emissivity of plate surfaces $\varepsilon=0.9$ and the weld process efficiency $\eta=80 \%$. In the thermal analysis, three-dimensional 8-node solid DC3D8 elements are used.

To speed up-the simulation process, the mechanical analysis is conduced simultaneously in one step, without using the element and birth technique [25]. In the mechanical analysis, an elastic-perflectly plastic behavior of the material is assumed. The same finite element mesh that consists of a 19,188 finite element mesh (Fig. 5 ) as in the thermal analysis is used, with only the finite element type being converted to C3D8I. The influence of the metal phase transformation is not considered in this study because its influence on the residual stress field and deformations can be neglected in low-carbon steel [26,27]. Creep material behavior is also neglected because the thermal cycles during the welding are of very short time duration. In doing so, the total strain increments can be decomposed into three components:

$$
d \varepsilon^{\text {total }}=\left\{d \varepsilon^{e}\right\}+\left\{d \varepsilon^{p}\right\}+\left\{d \varepsilon^{t h}\right\}
$$

where $\left\{d \varepsilon^{e}\right\},\left\{d \varepsilon^{p}\right\}$ and $\left\{d \varepsilon^{\text {th }}\right\}$ are elastic, plastic and thermal strain increments, respectively. Furthermore, in all numerical simulations it is assumed that the base metal and weld filler metal have the same thermal and mechanical properties.

The mesh sensitivity of the full (global) model, using the submodeling technique, is conducted on a small volume, $217 \mathrm{~mm} \times 99 \mathrm{~mm} \times 20 \mathrm{~mm}$, in the weld and its vicinity where the temperature gradients are very high. The location of the submodeling is shown in Figs. 2 and 5. It should be noted that the submodel mesh is created with a very high dense finite element mesh. It is clear, that the use of such dense finite element meshes in the full global model can lead to thermal and mechanical simulations which are computationally unsolvable. The dimensions of the submodel and the number of finite elements of the submodel are given in Table 2.

Additionally, a comparison is given between the finite element number of the submodel and the equivalent volume of the same dimensions in the full global model. All numerical simulations in this study are performed by using the Abaqus/Standard software.

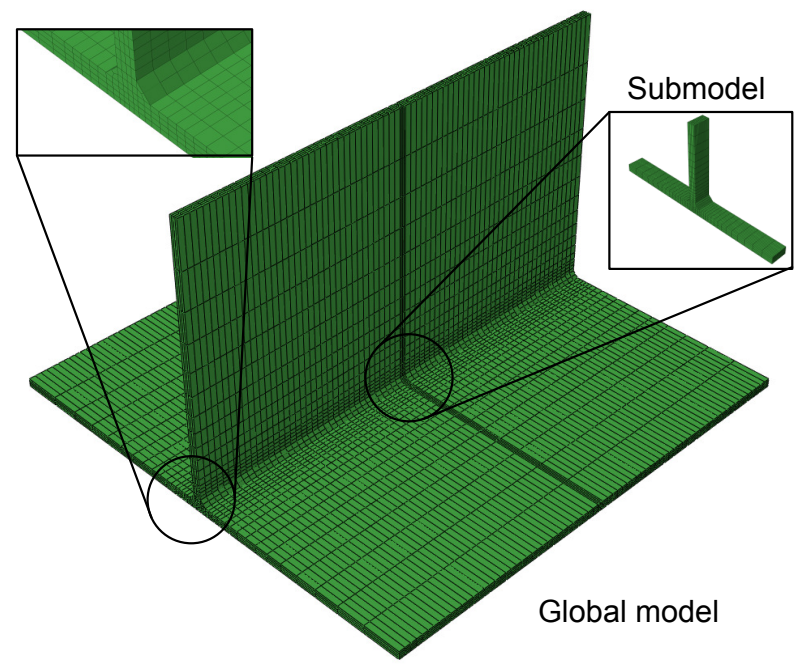

Figure 5. Typical finite element mesh

Table 2. Dimensions and number of finite elements of submodel and equivalent part of global model

\begin{tabular}{|l|l|l|}
\hline Name & Dimensions & $\begin{array}{l}\text { Number of finite } \\
\text { elements }\end{array}$ \\
\hline Global model* & $\begin{array}{l}217 \mathrm{~mm} \times 99 \mathrm{~mm} \times \\
20 \mathrm{~mm}\end{array}$ & 1092 \\
\hline Submodel & $\begin{array}{l}217 \mathrm{~mm} \times 99 \mathrm{~mm} \times \\
20 \mathrm{~mm}\end{array}$ & 22,320 \\
\hline
\end{tabular}

(*equivalent volume to submodel volume)

\section{RESULTS AND DISCUSSION}

The temperature time-history of node $\mathrm{E}$ which is located at the bottom surface of the horizontal plate (Fig. 2) for 
the first $150 \mathrm{~s}$ after the beginning of the welding process is given in Fig. 6. It is obvious that the temperature time-history of the global model and submodel are almost identical. More detailed peak temperature comparisons after the first and second weld pass are given in Figs. 7 and 8, respectively. The peak temperatures of the global model are $1 \%$ higher than in the submodel. Further submodeling with meshes of higher density has no additional influence on the submodel temperatures, and it can be stated that the temperatures converge. Keeping this in mind, it can be concluded that the global mesh for the thermal analysis is properly designed.

The obtained longitudinal residual stress (stress in the welding direction) at the middle plane of the horizontal plate along line C-D (Fig. 2) for the global model and submodel is shown in Fig 9. Here, it is seen that the longitudinal residual stress of the global model and submodel coincide very well.

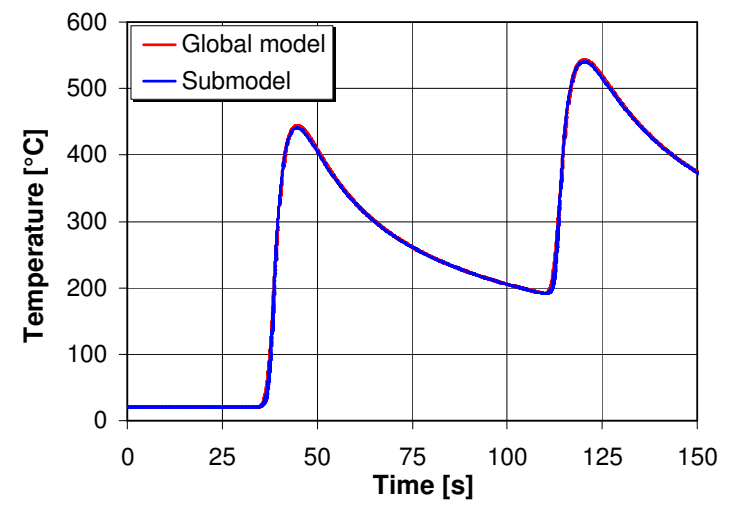

Figure 6. Temperature time-history at node E (Fig 2.) of global model and submodel

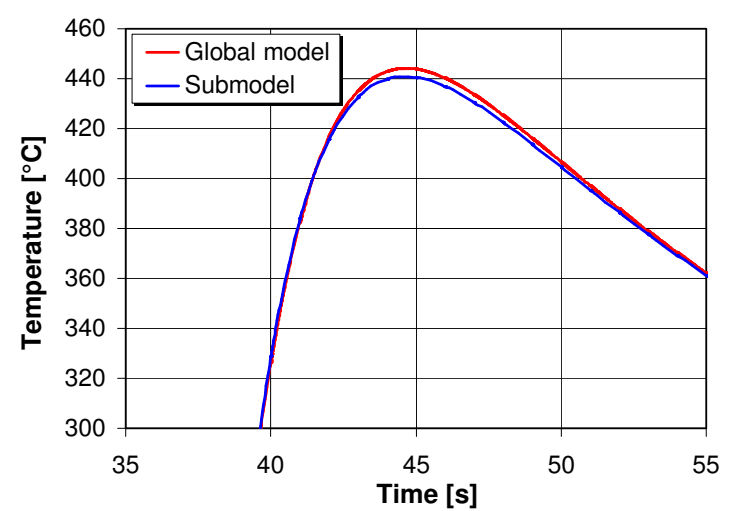

Figure 7. Peak temperature of global model and submodel after first weld pass

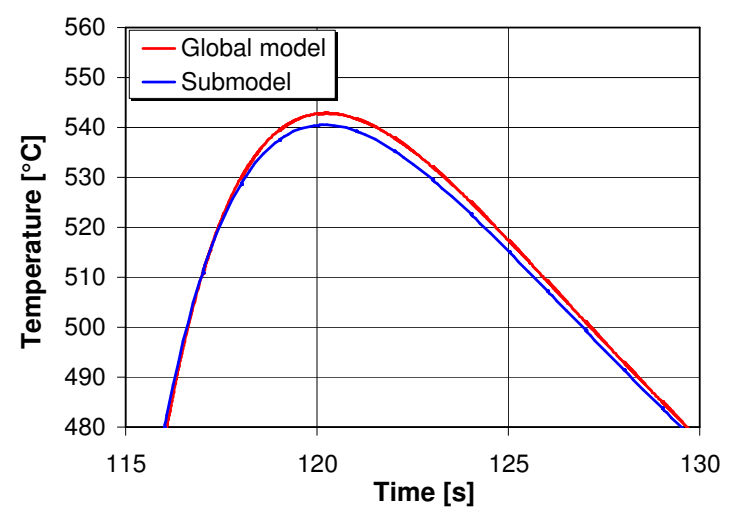

Figure 8. Peak temperature of global model and submodel after second weld pass
Due to a lack of experimental measurements in [23], the calculated longitudinal stresses are compared with the widely used analytical solution [28]. The peak longitudinal residual stresses is about 5\% higher than the analytical solution. The width of the numerically calculated tensile longitudinal stress zone is $66.3 \mathrm{~mm}$ and is the same for the global model and submodel, while the analytical calculated tensile residual stress zone is $69.2 \mathrm{~mm}$. The full field longitudinal residual stress distribution of the T-joint welded plates along CD line (Fig. 2), for the global model and submodel is given in Fig. 10.

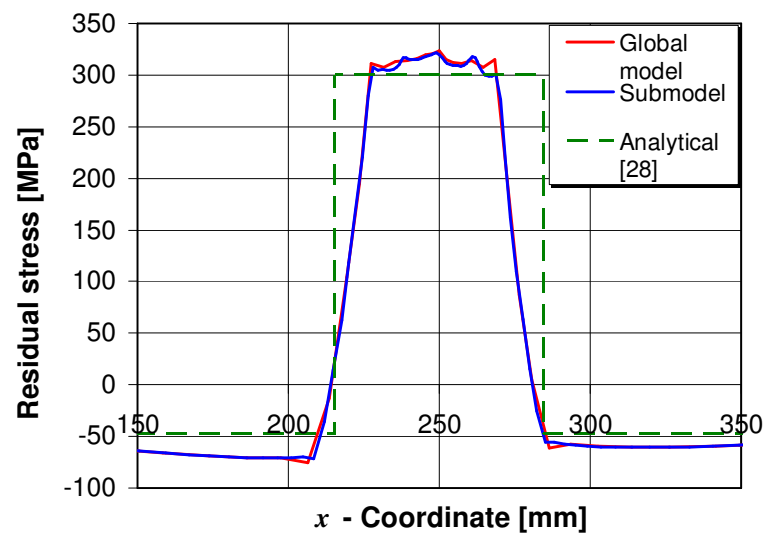

Figure 9. Longitudinal residual stress distribution of global model and submodel at middle surface of horizontal plate along C-D line shown in Fig. 2

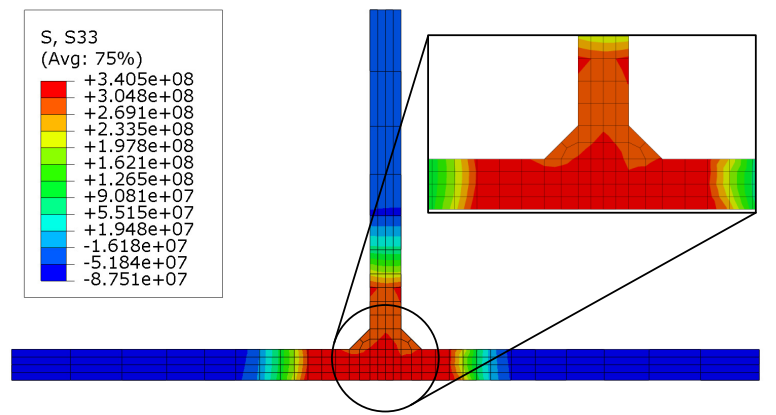

a)

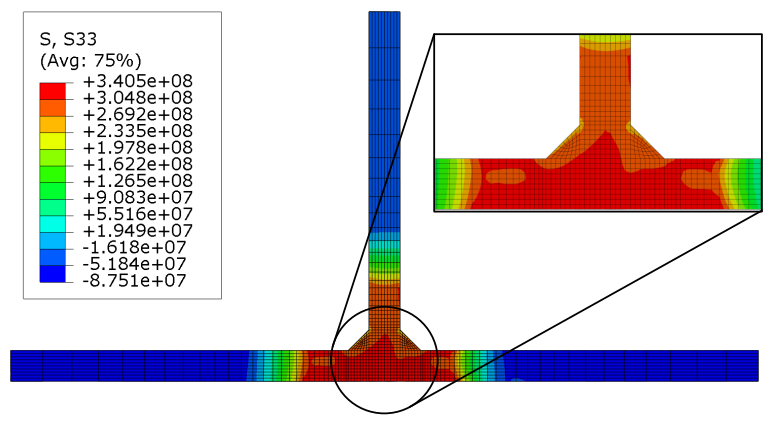

b)

Figure 10. Full field longitudinal residual stress distribution of T-joint welded plates along C-D line shown in Fig. 2: a) global model, b) submodel

The calculated transversal residual stress (stress parpendicular to the welding direction) at the middle plane of the horizontal plate along line C-D (Fig. 2) for both, global model and submodel is shown in Fig 11. As 
in the longitudinal stress comparison, it is noticeable that the longitudinal residual stress of the global model and submodel coincide very well. The full field transversal residual stress distribution of the $\mathrm{T}$-joint welded plates along C-D line (Fig. 2), for the global model and submodel is given in Fig. 12. Additionaly, the thickness of the transversal residual stress profile along F-G line (Fig. 2) is shown in Fig. 13. Here, node F is located on the lower surface of the horizontal plate, and node $\mathrm{G}$ on the lower surface of the horizontal plate. The obtained average through the thickness of the transverse residual stress difference between the global model and submodel is under $10 \%$.

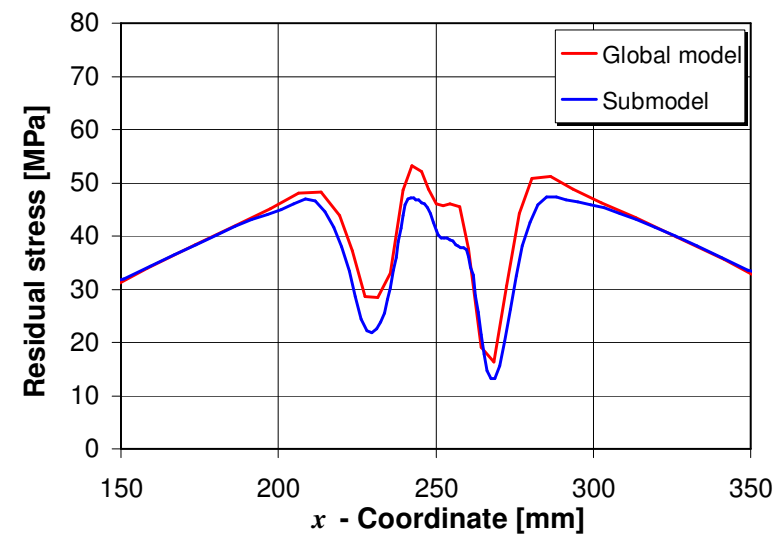

Figure 11. Transversal residual stress distribution of global model and submodel at middle surface of horizontal plate along C-D line shown in Fig. 2

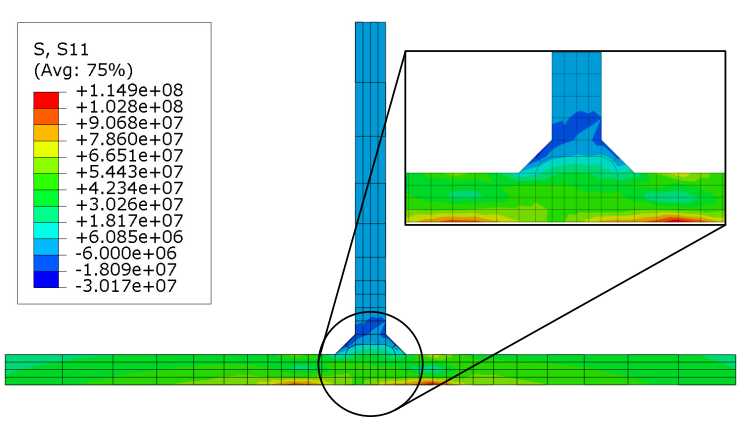

a)

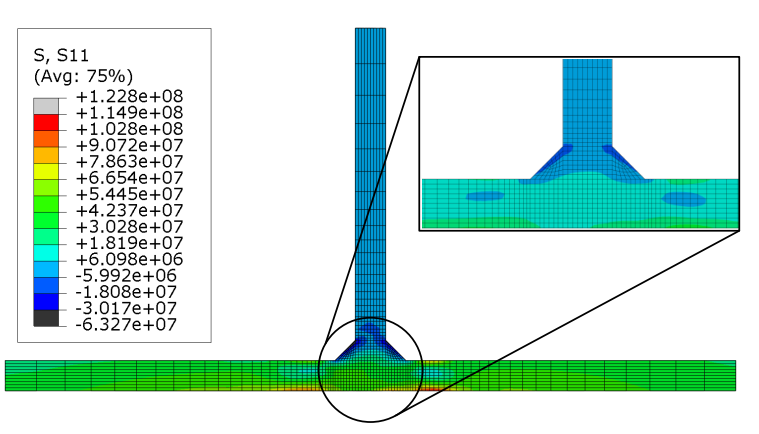

b)

Figure 12. Full field transversal residual stress distribution of T-joint welded plates along C-D line shown in Fig. 2: a) global model, b) submodel

A comparison between the vertical deflections of the horizontal plate at the middle surface along C-D (Fig. 2) between the global model and submodel is given in Fig. 14, while their full field comparison is given in Fig. 15. As it can be seen, the calculated vertical displacement of the global model and submodel correspond very well.

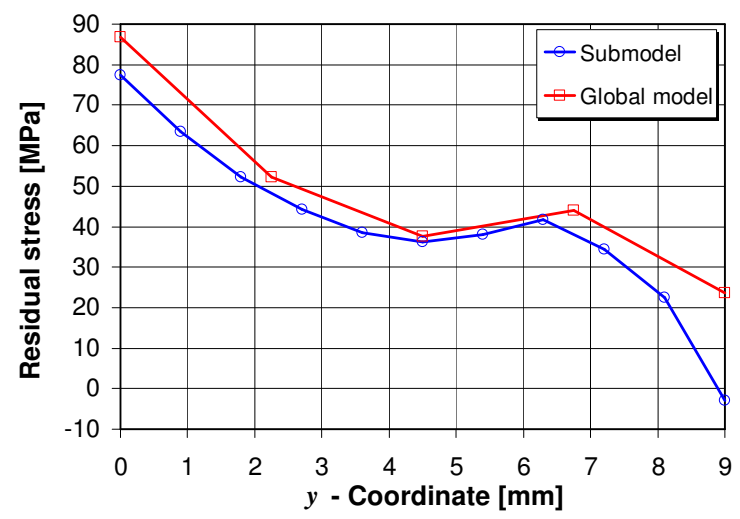

Figure 13. Through thickness transversal residual stress profile along F-G line shown Fig. 2

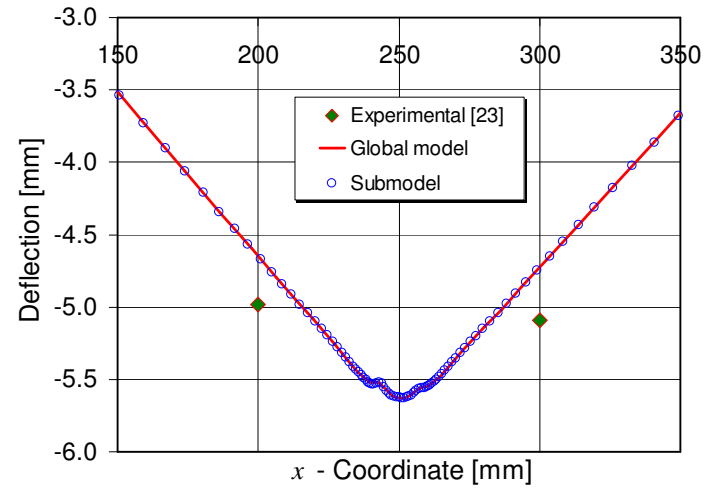

Figure 14. Deflection distributions of horizontal plate at middle surface along C-D line shown in Fig. 2

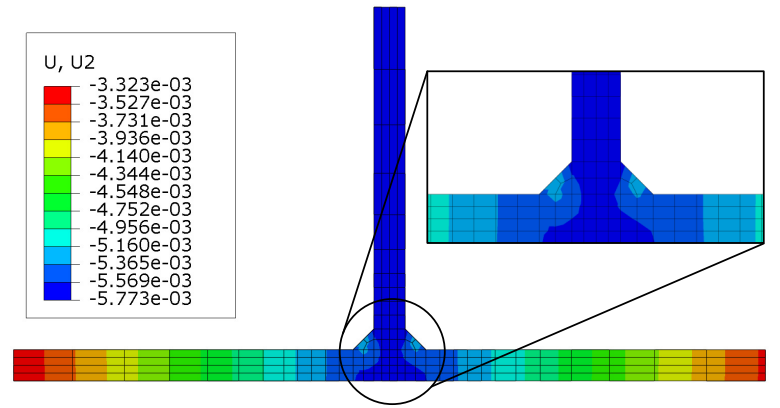

a)

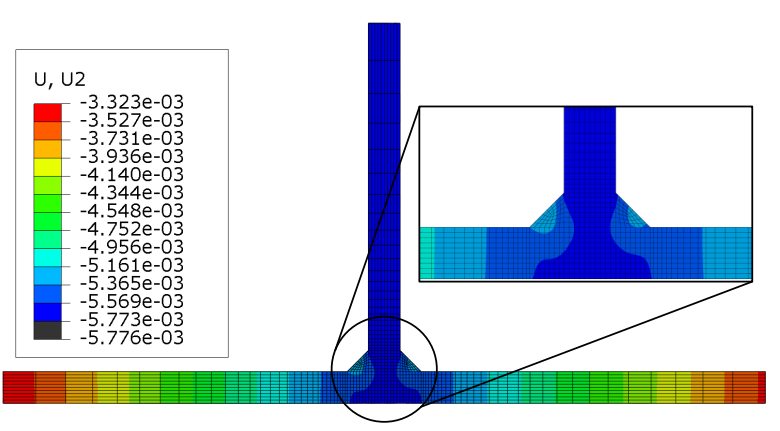

b)

Figure 15. Full vertical deflection field of T-joint welded plates along C-D line shown in Fig. 2: a) global model, b) submodel 
The calculated peak deflection for both model and submodel is $5.6 \mathrm{~mm}$.Keeping in mind that the calculated residual stresses and deflections of the global model and submodel are in good correlation and further submodeling has no influence on the results, it can be concluded that the global mesh for the mechanical analysis is properly designed. Some aspects of practical design with respects residual life estima-tions of structural components, using FEM or XFEM for stress analysis, are given in references [29-35].

\section{CONCLUSIONS}

In this study, the submodeling technique is applied on a T-joint fillet welded model to check the finite element mesh sensibility and to obtain a more accurate solution of temperature, displacement and residual stress field in the area of interest. Special attention is given to the investigation of the weld zone and its vicinity, where the thermal and residual stress gradients are very high. Considering the submodel dimensions to be very small at times, the finite element mesh can be very dense and the convergence of temperature, deformations and residual stress fields are much faster than on the full model in the numerical simulations. It can be concluded that the submodeling technique is a reasonable solution for this purpose.

\section{ACKNOWLEDGMENT}

The herein investigations described are part of the project "Centre of Excellence for Structural Health" (CEEStructHealth) supported by the EU under contract IPA2007/HR/16IPO/001-040513.

\section{REFERENCES}

[1] Oh, S.H., et al.: Evaluation of J-groove weld residual stress and crack growth rate of PWSCC in reactor pressure vessel closure head, Journal of Mechanical Science and Technology, Vol. 29, No. 3, pp. 1225-1230, 2015.

[2] Sedmak, S., et al.: Influence of multiple defects in welded joints subjected to fatigue loading according to SIST EN ISO 5817:2014, Structural Integrity and Life (eISSN 1820-7863), Vol. 18, No. 1. pp. 77-81, 2018.

[3] Predan, J., et al.: Fatigue crack propagation in threshold regime under residual stresses, International Journal of Fatigue, Vol. 32, No. 7, pp. 1050-1056, 2010.

[4] Chen, Z., et al.: Stress intensity factor-based prediction of solidification crack growth during welding of high strength steel, Journal of Materials Processing Technolology, Vol. 252, pp. 270-278, 2018.

[5] Lostado R.L., et al.: Using genetic algorithms with multi-objective optimization to adjust finite element models of welded joints, Metals, Vol. 8, No. 4, pp. 230, 2018.

[6] Lostado, R.L., et al.: Residual stresses with timeindenpendent cyclic plasticity in finite element analysis of welded joints, Metals, Vol. 7, No. 4, pp. 136, 2017.

[7] Maksimovic M., Vasovic I., Maksimovic K., Trišovic N., Maksimovic S., Residual life estimation of cracked aircraft structural components, FME Transactions, Vol. 46, No. 1, pp. 124-128, 2018.

[8] Sadeghi, S., et al.: Residual stress evaluation in friction stir welding of aluminum plates by means of acoustic emission and ultrasonic waves, FME Transactions, Vol. 46, No. 2, 230-237, 2018.

[9] Nguyen, K., et al.: Thermomechanical modeling of welding and galvanizing a steel beam connection detail to examine susceptibility to cracking, Materials Performance and Characterization, Vol. 7, No. 2, pp. 123, 2018.

[10] Shen, J., Chen, Z.: Welding simulation of fillet welded joint using shell elements with section integration, Journal of Materials Processing Technology, Vol. 214, No.11, pp. 2529-2536, 2014

[11] Rong, Y., et al.: Study of welding distortion and residual stress considering nonlinear yield stress curves and multiconstraint equations, Journal of Materials Engineering and Performance, Vol. 25, No. 10, pp. 4484-4494, 2016.

[12] Perić, M., et al.: Numerical analysis and experimental investigation in a T-joint fillet weld, Materials and Design, Vol. 53, pp. 1052-1063, 2014.

[13] Perić, M., et al.: Comparison of residual stresses in buttwelded plates using software packages Abaqus and Ansys, Scientific Technical Review (ISSN 1820-0206), Vol. 60 No. 3-4, pp. 22-26, 2010.

[14] Rezaei, A., et al.: Comparison of full 3D, shell/3D and inherent deformation numerical methods for prediction of out-of-plane welding-induced distortion, Journal of the Brazilian Society of Mechanical Sciences and Engineering, Vol. 40, No. 6, pp. 287, 2018.

[15] Huang, H., Murakawa, H.: Thermo-mechanical analysis of line heating process by an efficient and accurate multilevel mesh refining method, Marine Structures, Vol. 49, pp. 239-255, 2016.

[16] Seleš, K., et al.; Numerical simulation of a welding process using a prescribed temperature approach, Journal of Constructional Steel Research, Vol. 45, pp. 49-57, 2018.

[17] Elmesalamy, A.S., et al.: Measurement and modelling of the residual stresses in autogenous and narrow gap laser welded AISI grade $316 \mathrm{~L}$ stainless steel plates, International Journal of Pressure Vessels and Piping, Vol. 147, pp. 64-78, 2016.

[18] Teng, T.L., et al.: Effect of welding sequences on residual stresses, Computers and Structures, Vol. 81, pp. 273-286, 2003.

[19] Vacev, T., et al.: Plasticization conditions and strength of a welded beam-to-column connection in case of various detailing, Engineering Structures, Vol. 165, pp. 11-26, 2018.

[20] Marenić, E., et al.: On the calculation of stress intensity factors and J-integrals using the submodeling technique, Journal of Pressure Vessel Technology, Vol. 132, pp. 041203-1, 2010.

[21] Perić, M., et al.: An engineering approach for a T-joint fillet welding simulation using simplified material properties, Ocean Engineering, Vol. 128, pp. 13-21, 2016. 
[22] Bonifaz, E.A., Submodeling simulations in fusion welds, Journal of Multiscale Modelling, Vol. 4, No. 4, pp. 1-14, 2012.

[23] Deng, D., et al.: Determination of welding deformation in fillet-welded joint by means of numerical simulation and comparison with experimental measurements, Journal of Materials Processing Technology, Vol. 183, No. 2-3, pp. 219-225, 2007.

[24] Gannon, L., et al.: Effect of welding sequence on residual stress and distortion in flat-bar stiffened plates, Marine Structures, Vol. 23, No. 3, pp. 385-404, 2010.

[25] Perić. M., et al.: A simplified engineering method for a T-joint welding simulation, Thermal Science, Vol 22, No. 3, pp. S867-S873, 2018.

[26] Deng, D., FEM prediction of welding residual stress and distortion in carbon steel considering phase transformation effects, Materials and Design, Vol. 30, No. 2, pp. 359-366, 2009.

[27] Knoedel, P., et al.: Practical aspects of welding residual stress simulation, Journal of Constructional Steel Research, Vol. 132, pp. 83-96, 2017.

[28] Chen, B.Q., Soares G.C.: Effects of plate configurations on the weld induced deformations and strength of filletwelded plates, Marine Structures, Vol. 50, pp. 243-259, 2016.

[29] Grbovic, A., Rasuo, B.: FEM based fatigue crack growth predictions for spar of light aircraft under variable amplitude loading, Engineering Failure Analysis, Vol. 26, pp. 50-64, 2012.

[30] Boljanovic S., Maksimovic S., Computational mixed mode failure analysis under fatigue loadings with constant amplitude and overload, ENGINEERING FRACTURE MECHANICS, (2017), vol. 174, pp. 168179.

[31] Petrašinović, N., Petrašinović, D., Rašuo B., Milković D.: Aircraft Duraluminum Wing Spar Fatigue Testing, FME Transactions, Vol. 45, No. 4, pp 531-536, 2017.

[32] Petrašinović, D., Rašuo, B., Petrašinović, N.: Extended finite element method (XFEM) applied to aircraft duralumin spar fatigue life estimation, Technical Gazette, Vol. 19(3), pp. 557-562, 2012.

[33] Rasuo, B., Grbovic, A., Petrasinovic, D.: Investigation of fatigue life of 2024-T3 aluminum spar using Extended Finite Element Method (XFEM), SAE International Journal of Aerospace, 6 (2013-01-2143), pp 408-416, 2013.

[34] Grbovic A., Rasuo B.: Use of modern numerical methods for fatigue life predictions, in: Recent Trends in Fatigue Design, Branco R. (Ed.), Nova Science Publishers, New York. Chapter 2., pp.31-75, 2015.

[35] Kastratović, G., Vidanović, N., Grbović, A., Rašuo, B.: Approximate determination of stress intensity factor for multiple surface cracks, FME Transactions, Vol. 46, No. 1, pp 41-47, 2018.

\section{НУМЕРИЧКА АНАЛИЗА ЗАОСТАЛИХ НАПОНА У ЗАВАРЕНИМ ПЛОЧАМА У ОБЛИКУ Т-СПОЈА КОРИШЋЕЫЕМ ТЕХНИКЕ ПОДМОДЕЛИРАЊА}

\section{М. Перић, 3. Тонковић, К.С. Максимовић, Д. Стаменковић}

У оквиру овог рада примењена је техника подмоделирања на примеру заварених плоча у облику Т-споја, како би се проверила осетљивост мреже са коначним елементима, као и да се добију прецизније расподеле температура, померања и поља заосталих напона у завареном споју и у његовој околини где су градијенти температуре и напона веома високи. Процедура субмоделирања процеса заваривања приказана је корак по корак. Добијени резултати расподеле температуре, заосталих напона и померања веома добро се слажу са експерименталним мерењима и аналитичким решењима из литературе. 